\title{
AN OVERVIEW OF THE EUROPEAN PROFILE FOR LANGUAGE TEACHER EDUCATION ON THE LANGUAGE TEACHER EDUCATION REFORMS IN TURKEY
}

\author{
Gizem Arslan $^{1 *}$ \\ ${ }^{1}$ Near East University Graduate School of Educational Sciences, PhD Candidate \\ gizem.arslan@kisbu.edu.tr \\ Correspondence: gizem.arslan@kisbu.edu.tr
}

\begin{abstract}
English language is now the most commonly used lingua franca all over the world and has become an international language. Consequently, learning English is an important objective in the education system in every country as well as the EU member countries. This status of English language results in some fundamental changes in the foreign language education and foreign language teacher education policies of almost every country globally. This paper addresses the question whether the European Profile for language teacher education affects the foreign language teacher education policies and reforms in Turkey. The study also focuses on the general European profile for foreign language teacher education on Turkey contexts as well as the influence of the European profile for language teacher education on the foreign language teacher education reforms in Turkey.
\end{abstract}

Keywords: English language, foreign language education, language teacher education profile in Europe, language teacher education reform in Turkey

\section{Introduction}

English Language is the most commonly used lingua franca in all over the world. It cannot be ignored that language awareness, communicative competence and professional qualifications can only be provided via a specific language teacher education policy (Edelenbos, Johnstone, \& Kubanek, 2006). In general, any language teacher education curriculum must meet prospective teachers' needs and interests through developing their language professional. This contribution can rely on qualified language teachers. However, many countries indicated the lack of qualified language teachers, although learning environment and resources affect learners' language learning process (Enever \& Moon, 2009). Due to the demands, English language into global curriculum is one of the main parts of education policy developments around the world (Garton, Fiona, \& Burns, 2011). As the policy makers, EU member countries have created many disciplines about language learning and teaching. This paper disscusses whether general profile for foreign language teacher education in Europe affects the foreign language teacher education policies and reforms in Turkey. To expound the general profile for language teacher education in EU member countries, this study depended on the European Profile for Language Education: A Frame of Reference by Michael Kelly and Michael Grenfell supported by the European Commission. Instead of examining each EU member country policy one by one, this frame will help us to view the general manner of language teacher education policy in Europe (Grenfell \& Kelly, 2004) 
In terms of the overview of the effects of the general European profile for language teacher education on language education policies implemented in Turkey, this study examined the pre-service language teacher education reform in 2005 and the in-service language teacher education reform in 2018 because the well-organized European language teacher education profile was apparently shaped in 2004 (Karatsiori, 2016).

\subsection{Definition of Technology and Technology Integration}

This frame presents a guide to 'The European Profile for Language Teacher Education which contains a number of strategies for its implementation and application. It was developed by Professor Michael Kelly and Dr. Michael Grenfell supported by the European Commission. It is currently operated to consult through its findings from a range of teacher education programmes across Europe.

This profile is not designed as a compulsory set of rules and regulations for language teacher education. It has been designed to present a frame of reference in order that language teacher educators and policy makers will be able to adapt to their existing curriculum.

In addition, this profile consists of 40 items which could be included in a language teacher education programme to train qualified language teachers with the necessary skills and knowledge to promote their professional improvement. Also, it has four sections: Structure, Knowledge and Understanding, Strategies and Skills, and Values. The 40 items describing the important factors of language teacher education in Europe are listed below (see Figure 1).

\begin{tabular}{|c|}
\hline Structure \\
\hline $\begin{array}{l}\text { 1. A curriculum that integrates academic study and the practical experience } \\
\text { of teaching }\end{array}$ \\
\hline 2. The flexible and modular delivery of initial and in-service education \\
\hline 3. An explicit framework for teaching practice (stage/practicum) \\
\hline 4. Working with a mentor and understanding the value of mentoring \\
\hline 5. Experience of an intercultural and multicultural environment \\
\hline $\begin{array}{l}\text { 6. Participation in links with partners abroad, including visits, exchanges or } \\
\text { ICT links }\end{array}$ \\
\hline $\begin{array}{l}\text { 7. A period of work or study in a country or countries where the trainee's } \\
\text { foreign language is spoken as native }\end{array}$ \\
\hline $\begin{array}{l}\text { 8. The opportunity to observe or participate in teaching in more than one } \\
\text { country }\end{array}$ \\
\hline $\begin{array}{l}\text { 9. A European-level evaluation framework for initial and in-service teacher } \\
\text { education programmes, enabling accreditation and mobility }\end{array}$ \\
\hline 10. Continuous improvement of teaching skills as part of in-service education \\
\hline 11. Ongoing education for teacher educators \\
\hline 12. Training for school-based mentors in how to mentor \\
\hline $\begin{array}{l}\text { 13. Close links between trainees who are being educated to teach different } \\
\text { languages }\end{array}$ \\
\hline
\end{tabular}




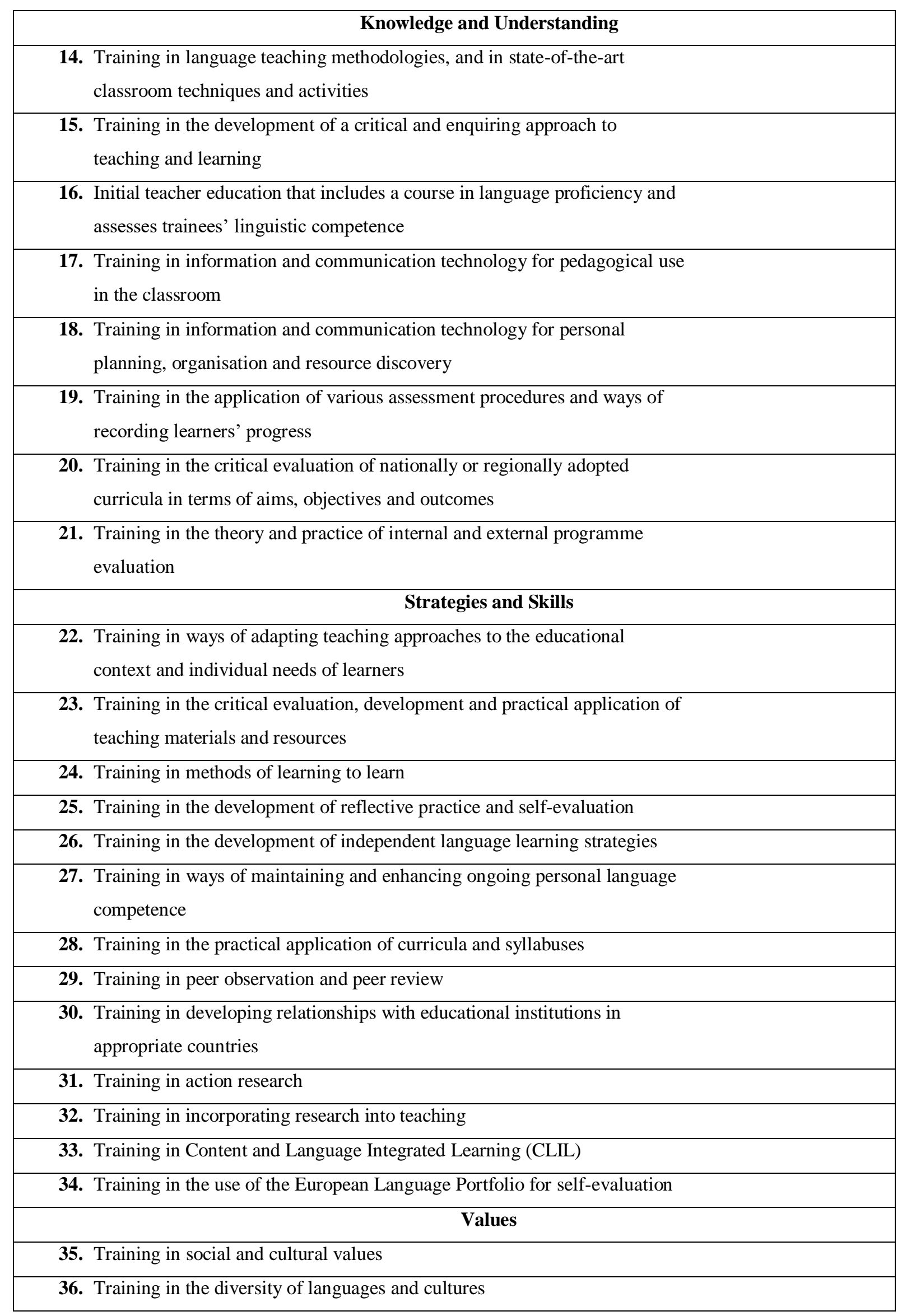




\begin{tabular}{|l|}
$\begin{array}{l}\text { 37. Training in the importance of teaching and learning about foreign languages } \\
\text { and cultures }\end{array}$ \\
\hline 38. Training in teaching European citizenship \\
39. Training in team-working, collaboration and networking, inside and outside \\
the immediate school context \\
\hline 40. Training in the importance of life-long learning
\end{tabular}

Figure 1. The Descriptors in the European Profile for Language Teacher Education (Grenfell \& Kelly, 2004)

\section{Method}

This paper discusses whether the European profile for language teacher education affects the language teacher education reforms in Turkey. In this qualitative research, the data were collected through scientific literature and the document analysis were mapped to the research problems.

In this study, the main research problem is "What is the effects of the European profile for language teacher education on the language teacher education reforms in Turkey?". Based on this main research problem, the sub-research questions are as follows:

1. What is the background to language teacher education history in Turkey?

2. What are the effects of the European profile for language teacher education on the 2006 language teacher education reform in Turkey?

3. What are the effects of the European profile for language teacher education on the 2018 language teacher education reform in Turkey?

\section{Findings and Discussion}

\subsection{The General Background to Language Teacher Education History in Turkey}

The foreign language education in Turkey were designed as religious, political, and scientific purposes and Arabic language was the most common foreign language in religious education and subsequently German and French were very important for political and scientific fields in the Ottoman Empire (Sarıboğa Alagöz, 2006).

In The Ottoman Empire, the Western languages were not considered important because of the political relationship. However, learning Western languages became important between goverments in 1839. After this period, the talented young people who were chosen by the Ministry of Education went to France to learn French language in order to teach French language in the country (Tok, 2006). After this attempt, Galatasaray Sultanisi started to teach French language in 1868 and it was very important event for the history of language teacher education in Turkey.

In the Republic of Turkey, The first language teacher education programme which was French language was established at the Gazi Institute in 1941 and subsequently English language department was established in 1944 and German language department was established in 1947 (Demirel, 1991). These programme was designed as 4 years and the name of the school was changed as Gazi High Teacher School in 1982 (Akyüz, 2009). 
In 1997, the language teacher education programme was changed in terms of getting teaching certificates over 31 hours in 34 universities in Turkey. Also, it was based on teaching practice and theoritical knowledge (Seferoğlu, 2004).

\subsection{The Language Teacher Development Reform in 2006 as Pre-service}

This study discusses the language teacher education reforms after 2004 because the general European profile were apparently developed in that time (Karatsiori, 2016). Due to the attempt of Turkey to become EU member, the language education policy has been innovated and the duration of high schools became from three years to four years. In the English Departments in high schools, English classes increased to twelve hours in a week in order to promote the prepaaration of higher education (Kırkgöz, 2007).

Actually, the language teacher education reform in 2006 was the revision of 1997 curriculum. In order to adapt to the EU standards, the previous curriculum has been innovated in terms of aims, teaching materials, assessment and the role of teacher. This curriculum reform is more comprehensive and it focused on more detailed theoritical information about use of appropriate teaching resources for different groups such as young learners and adolescents, curriculum design issues, and the difference between language acquisition and language learning; the educational theories on how people learn a foreign language.

In terms of the objectives and role of teacher, the focus was commucative language teaching following functional-notional and skill-based syllabus model and a teacher is a facilitator. To provide 'learner autonomy', the curriculum gives opportunity to students for strategy training. In addition, the assessment is based on performance-based implementing portfolios instead of paper and pencil tests as a traditional method (Ersöz, Çakır, Cephe, \& Peker, 2006).

To provide these, language teacher education curriculum were designed as the curriculum of foreign language education in primary. A language teacher was trained to be aware of learners' needs and interests following educational psychology theories through implementing language teaching methods, performance-based assessments, etc. Also, in order to support learning the other languages as becaming a qualified teacher. The curriculum gives opportunity to learn the other foreign languages such as French, German, etc. For teaching traning, teaching practice has very significant importance. At the end of the language teaching programme, the curriculum provides teaching observation and pratice in a language classroom environment. (COHE, 2006)

When we examine the European Profile for language teacher education, this curriculum has some similarities. Firstly, according to first item, curriculum should integrate academic study and the practical experience. Teaching practice also imposed on the 2006 ELT Curriculum in Turkey. The focus is on training in language teaching methodologies, and in state-of-the-art classroom techniques and activities applying various assessment procedures and ways of recording learners' progress according to the European profile, whereas the 2006 ELT Curriculum provided the teaching approaches and learning strategies in terms of learners' needs and interests and implementing performance-based assessments.

In 2004, a project called 'Traning Trainers on European Union' started to present many aspects of a qualified teacher through seminars, coferences, projects and publications. The European Union announced a guidebook to help this new policy in Turkey (Ustel, 2006) and the important component of this guidebook was the colloboration of various EU member countries on various educational programmes such as Erasmus, Socrates, and Comenius. 
Thus, Turkey was accepted for this programmes. (Socrates, 2006) This supported for language teachers in terms of having experiences in an intercultural and multicultural environment in light of the European profile for language teacher education.

\subsection{The In-service Language Teacher Education (2018)}

Turkish Higher Education Council (HEC) had attempted to change teacher education programmes because of the claims that "the existing system is deficient in its goals, accomplishments and responsiveness to global changes." (Kırkgöz, English Education Policy in Turkey, 2017). In 2018-2019 academic year, all the curriculum of the faculties of Educational Sciences has been changed and this reform is based on several changes in course names and credits following theory-based pedagogical courses and teaching practice from the first semester to the final year (Öztürk \& Aydın, 2019).

The one of the important issue in pre-service policy is about English teacher education programme because real life implementation and practice are problematic although objectives and outcomes are clearly expressed in the documents. Despite the fact that the in-service language teacher education programme is new, it is a little bit similar to previous one in terms of the influence of the European Profile for language teacher education. The general changes in the curriculum is based on the course names, credits and contents especially in elective courses (COHE, 2018).

When we compare the European profile for language teacher education with this reform, the new curriculum focuses on Content and Language Integrated Learning (CLIL) and supports the importance of life-long learning and social and cultural values through following its elective courses.

However, we cannot say that the European profile for language teacher education affects the new language teacher education in Turkey. A revision of European profile for language teacher education or European language teacher policies may lead to examine the new language teacher education reform as a further study.

\section{Conclusion}

This paper addresses whether the European Profile for language teacher education affects the foreign language teacher education policies and reforms in Turkey. It depends on the European Profile for Language Education: A Frame of Reference by Michael Kelly and Michael Grenfell supported by the European Commission in 2004 through comparing the general profile with two language teacher education reforms in Turkey. The European profile for language teacher education affects the language teacher education reform in 2006. Because of Turkey's attempt to join EU, the educational reform conducted in 2006 especially in language teacher education programme. This reform was based on the language teaching methodologies, teaching practice, selecting appropriate materials and assessment. Also, students exchanging project like Erasmus and Socrates shows us the effect of European education policy in terms of experience of an intercultural and multicultural environment in 2006. Although there are some similarities between the European profile for language teacher education and language teacher education reform in 2018 in terms of CLIL and social and cultural values, we cannot say that the European profile for language teacher education affects the 2018 language teacher education reform in Turkey. If there is a revision of European profile for language teacher education or European language teacher policies may lead to examine the new language teacher education reform as a further study. 
When we examine the pre-service and in-service language teacher education reforms in Turkey, we see that foreign language teacher education policies in Turkey were determined by political events and governmental policies rather than philosophy of education (Nergis, 2011). On other hand, according to Öztürk and Aydın, it is still an issue whether we fail or not on language teacher education in Turkey (Öztürk \& Aydın, 2019). 


\section{References}

Akyüz, Y. (2009). Türk Ĕ̈itim Tarihi. Ankara: Pegem.

Demirel, Ö. (1991). Türkiye'de yabancı dil öğretmeni yetiştirmede karşılaşılan güçlükler. Hacettepe Üniversitesi Eğitim Fakültesi Dergisi, 25-39.

Edelenbos, P., Johnstone, R., \& Kubanek, A. (2006). The main pedagogical principles underlying the teaching of languages to very young learners, languages for the children of Europe, published research, good practice \& main principles. London: European Commission.

Enever, J., \& Moon, J. (2009). New global contexts for teaching primary ELT: Change and challenge. Young Learner English language policy and implementation: (pp. 5-21). Garnet Education.

Ersöz, A., Çakır, A., Cephe, P., \& Peker, B. (2006). English Language Curriculum for Primary Education. Ankara: Ministry of Education.

Garton, S., Fiona, C., \& Burns, A. (2011). Investigating global practices in teaching English to young learners. ELT Research Papers, 35-67.

Grenfell, M., \& Kelly, M. (2004). European Profile for Language Teacher Education: A Frame of Reference. Southampton: Peter Lang Publishers.

Karaata, C. (2010). Milli Eğitim Bakanlığg'nda görevli İngilizce öğretmenlerinin hizmet için eğitimine ilişkin öneriler. Milli Ĕgitim Dergisi, 107-129.

Karatsiori, M. (2016). European profile for language teacher education: Meeting the challenge for sharing common competences, knowledge, strategies and values. Cogent Education.

Kurkgöz, Y. (2007). English Language Teaching in Turkey: Policy Changes and their Implementations. RELC Journal, 216-228.

Kırkgöz, Y. (2017). English Education Policy in Turkey. Springer International Publishing.

Nergis, A. (2011). Foreign language teacher education in Turkey: A historical overview. Procedia Social and Behavioral Sciences, 181-185.

Öztürk, G., \& Aydın, B. (2019). English Language Teacher Education in Turkey: Why Do We Fail and What Policy Reforms Are Needed? Anadolu Journal of Educational Sciences International, 181-213.

Sarıboğa Alagöz, N. (2006). Türkiye'deki ve Hollanda'daki Ingilizce öğretmenliği programlarının karşılaş̧ırılması. Eskişehir: Eskişehir University.

Seferoğlu, G. (2004). A study of alternative English teacher certification practices in Turkey. Journal of Education for Tteaching, 151-159.

Tok, H. (2006). Avrupa birliği ülkelerinde ve Türkiye'de uygulanan yabancı dil öğretimi programlarının karşılaş̧ırılması. Malatya: İnönü University.

Ustel, L. (2006). Öğretmenler için AB Klavuzu, European Union Guidelines for Teachers. Ankara: Ministry of Education.

(2006). COHE. Ankara: The Council of Higher Education.

Socrates. (2006). Retrieved from Socrates: www.http://ua.gov.tr.tr. 
COHE. (2018). Ankara: The Higher Education Council. 